\title{
Reevaluation of taxonomic structure of the root vole (Microtus oeconomus Pallas, 1776, Rodentia, Arvicolidae) from the territory of the former USSR based on evidence from craniometric and molecular data
}

\author{
Natalya I. Abramson \& Elena P. Tikhonova
}

\begin{abstract}
Uni- and multivariate analyses of skull 27 measurements of $353 \mathrm{M}$. oeconomus specimens from 46 sites, covering most part of the range in Eurasia and 11 specimens from Alaska revealed the existence of three morphologically distinct groups. Therewith, two of them, uniting all samples from Palaearctic formed two clusters joined together, and each represented a set of samples that in its turn could be defined as so-called western and eastern groups. An approximate border between these groups can be allocated in the region of the Lena River. Morphological data are in good agreement here with molecular data in uniting all root voles from the European North in one group. Voles from Urals, Western Siberia and Krasnoyarsk Territory morphologically are very close to this north-European group, though molecular data place them in another clade. Distinction on western and eastern groups disagrees with molecular data. We relate this discrepancy only with poor sampling in molecular studies to the current moment. The third group is formed by samples from Chukotka, Alaska and Kamchatka and constitutes the so-called Beringian clade, what is in a good agreement with molecular data. However poorly studied with molecular methods the voles from Kamchatka differ seriously from other representatives of the group and no doubt that taxonomically they represent an independent taxon of subspecies rank.
\end{abstract}

KEY WORDS: root vole, morphometric variation, intraspecies taxonomy, mitochondrial cytochrome b gene, discriminant functions.

Natalya I. Abramson [lemmus@zin.ru] and Elena P. Tikhonova [ellobius@zin.ru], Zoological Institute, Russian Academy of Science, Universitetskaya nab. 1, Saint Petersburg 199034, Russia.

\section{Ревизия таксономической структуры полевки-экономки (Microtus oeconomus Pallas, 1776, Rodentia, Arvicolidae) c территории бывшего СССР по краниометрическим и молекулярным данным}

\section{Н.И. Абрамсон, Е.П. Тихонова}

РЕЗЮМЕ. Одно- и многомерный анализ 27 черепных признаков у 353 экземпляров M. oеconomus из 46 точек, охватывающих большую часть ареала вида в Евразии, и 11 экземпляров с Аляски выявил наличие трех морфологически различных групп. При этом две из них, объединенные в один кластер, включают в себя все выборки из Палеарктики, каждая из которых, в свою очередь, представлена набором выборок, которые можно условно обозначить как западная и восточная группы с условной границей, проходящей в районе р. Лены. Морфологические данные хорошо согласуются с молекулярными данными в объединении всех полевок с Европейского севера в одну группу. Полевки с Урала, Западной Сибири и Красноярского края морфологически очень близки к этой группе, хотя молекулярные данные относят их к другой кладе. Разделение на западную и восточную группы также не согласуется с молекулярными данными. Мы связываем это несовпадение с очень малым количеством материала, исследованного молекулярными методами. Третья группа, состоящая из выборок с Чукотки, Камчатки и Аляски, образует самостоятельный кластер, резко отличающийся от предыдущих двух и совпадающий с так называемой Берингийской молекулярной кладой. При этом недостаточно изученная молекулярными методами выборка с Камчатки сильно отличается от остальных и без сомнения заслуживает выделения в самостоятельный подвид.

КЛЮЧЕВЫЕ СЛОВА: полевка-экономка, морфометрическая изменчивость, внутривидовая таксономия, митохондриальный ген цитохром б, дискриминантные функции. 


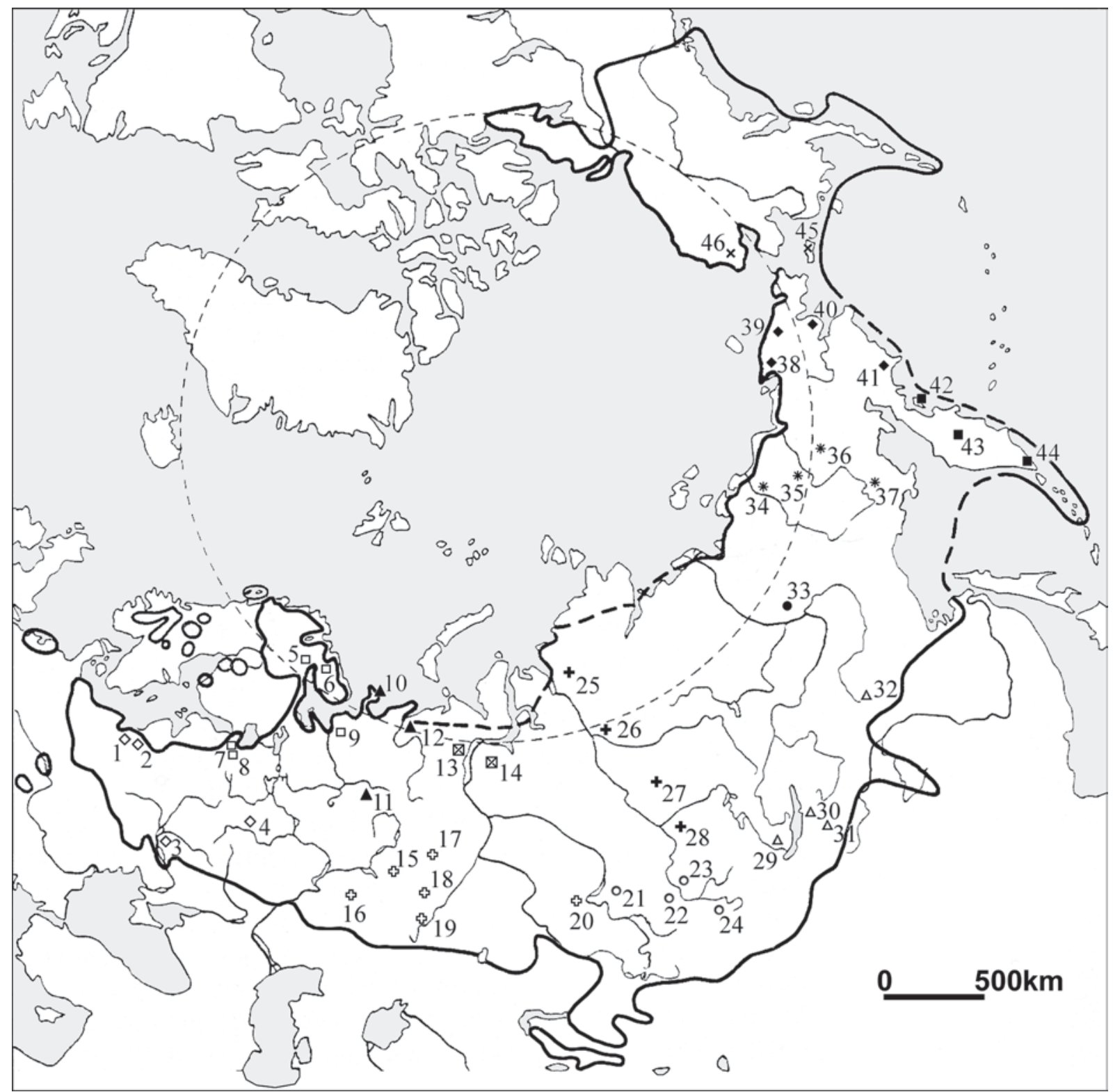

Figure 1. Map of distribution range of Microtus oeconomus (after Vorontsov et al., 1986). Numbers of samples correspond to those in Tab. 1.

\section{Introduction}

The root vole (Microtus oeconomus Pallas, 1776) is a widely distributed species that occurs in wet meadows of both Arctic and temperate biotas from northwest Europe up to western parts of Canada and are found on many north Pacific islands (Fig. 1). The fossil remains of root vole are known from the beginning of the Early Pleistocene. In the Pleistocene the species occurred significantly far to the south and west of the recent borders of its range. Apparently the species originated in the forest-steppe zone that in the Middle and Late Pleistocene extended from the Western Europe to the east along the middle part of the West-Siberian lowland (Galkina, 1980). In the beginning of the Holocene alongside with formation of continuous forest belt the spe- cies range was divided into the northern, tundra and more southern forest-steppe parts (Gromov \& Polyakov, 1977). Along the southern border of the range a whole number of isolated plots are known (Gromov \& Erbaeva, 1995). The stable karyotype $(2 n=30)$ is typical of this species (Makino, 1950; Matthey, 1954; Král, 1972; Nadler et al., 1976; Kozlovskii \& Khvorostyanskaya, 1978; Belyanin et al., 1986; Vorontsov et al., 1986).

The intraspecies variation and taxonomic structure of this wide-ranged species is far from being clear. On the base of size and pelage color variation more than 15 subspecies mostly from the territory of the former USSR are described (Gromov \& Erbaeva, 1995). Root voles of Far East and Beringian regions appeared to be most studied (Kostenko \& Allenova, 1986, 1989; Lance \& Cook, 1998; Kostenko, 2000; Frisman et al., 2003; 
Table 1. Geographic location and size of the samples of Microtus oeconomus examined.

\begin{tabular}{|c|c|c|c|c|}
\hline $\begin{array}{l}\text { Subspecies and } \\
\text { total sample size } \\
\text { (n) }\end{array}$ & $\begin{array}{c}\text { Sample } \\
\text { number in Fig. } \\
1\end{array}$ & Locality (region or closest city) & sample size & $\begin{array}{l}\text { Phylogeographic clades (after } \\
\text { Brunhoff et al., 2003; Galbreath \& } \\
\text { Cook, 2004) }\end{array}$ \\
\hline \multirow{4}{*}{$\begin{array}{l}\text { M. o. stimmingi } \\
\text { Nehring, } 1899 \text {, } \\
\mathrm{n}=19\end{array}$} & 1 & Kaliningrad Province & 1 & No data \\
\hline & 2 & Lithuania & 2 & Central European \\
\hline & 3 & Chernigovsk Province & 3 & No data \\
\hline & 4 & Moscow Province & 13 & North European \\
\hline \multirow{5}{*}{$\begin{array}{l}\text { M. o. ratticeps } \\
\text { Kayserling et } \\
\text { Blasius, } 1841 \text {, } \\
\mathrm{n}=34\end{array}$} & 5 & Kandalaksha Reserve & 11 & No data \\
\hline & 6 & Kola Peninsula & 10 & No data \\
\hline & 7 & Leningrad Province & 5 & No data \\
\hline & 8 & Novgorod Province & 2 & No data \\
\hline & 9 & Arkhangel'sk Province & 6 & No data \\
\hline \multirow{3}{*}{$\begin{array}{l}\text { M. o. petschorae } \\
\text { Ognev, 1944, } \mathrm{n}=29\end{array}$} & 10 & North-East shore of Kanin Peninsula & 16 & North European \\
\hline & 11 & Syktyvkar & 6 & No data \\
\hline & 12 & Pechora Bay & 7 & North European \\
\hline \multirow{2}{*}{$\begin{array}{l}\text { M. o. hahlovi } \\
\text { Scalon, } 1935 \text {, } \\
\mathrm{n}=20\end{array}$} & 13 & $\begin{array}{l}\text { Right shore of Ob' River Mouth, } \\
\text { Yamal Peninsula }\end{array}$ & 5 & No data \\
\hline & 14 & Shchuch'e Lake, Yamal Peninsula & 15 & No data \\
\hline \multirow{6}{*}{$\begin{array}{l}\text { M. o. oеconomus } \\
\text { Pallas, } 1776, \mathrm{n}=22\end{array}$} & 15 & Bashkiriya & 3 & No data \\
\hline & 16 & Orenburg & 3 & No data \\
\hline & 17 & Ekaterinburg & 5 & Central Asian \\
\hline & 18 & Chelyabinsk & 2 & No data \\
\hline & 19 & Kurgan & 6 & Central Asian \\
\hline & 20 & Novosibirsk & 3 & Central Asian \\
\hline \multirow{4}{*}{$\begin{array}{l}\text { M. o. altaicus } \\
\text { Ognev, 1944, n=36 }\end{array}$} & 21 & Altai & 17 & No data \\
\hline & 22 & Minusinsk & 4 & No data \\
\hline & 23 & Khakas siya & 2 & No data \\
\hline & 24 & Tuva & 13 & No data \\
\hline \multirow{4}{*}{$\begin{array}{l}\text { M. o. kjusjurensis } \\
\text { Koljuschev, 1935, } \\
\mathrm{n}=41\end{array}$} & 25 & West Taimyr Peninsula & 9 & No data \\
\hline & 26 & Turukhansk, Kras noyarsk Territory & 21 & No data \\
\hline & 27 & Evenkiya & 7 & No data \\
\hline & 28 & Boguchan, Krasnoyarsk Territory & 4 & Central Asian \\
\hline \multirow{4}{*}{$\begin{array}{l}\text { M. o. dauricus } \\
\text { Kashchenko, 1910, } \\
\mathrm{n}=20\end{array}$} & 29 & Irkutsk & 5 & No data \\
\hline & 30 & Buryatiya & 6 & No data \\
\hline & 31 & Chita Province & 4 & No data \\
\hline & 32 & Tukuringra Ridge, Amur Province & 5 & No data \\
\hline $\begin{array}{l}\text { M. o. suntaricus } \\
\text { Dukelsky, } 1928, \\
\mathrm{n}=25\end{array}$ & 33 & Central Yakutia & 25 & No data \\
\hline \multirow{4}{*}{$\begin{array}{l}\text { M. o. koreni } \\
\text { G.Allen, 1914, } \\
\mathrm{n}=37\end{array}$} & 34 & Indigirka River & 9 & No data \\
\hline & 35 & Kolyma River & 14 & Central Asian \\
\hline & 36 & Omolon River & 8 & Central Asian \\
\hline & 37 & Magadan Province & 6 & Central Asian \\
\hline
\end{tabular}


Table 1 (continued).

\begin{tabular}{|c|c|c|c|c|}
\hline $\begin{array}{l}\text { Subs pecies and } \\
\text { total sample size } \\
\text { (n) }\end{array}$ & $\begin{array}{c}\text { Sample } \\
\text { number in Fig. } \\
1\end{array}$ & Locality (region or closest city) & sample size & $\begin{array}{l}\text { Phy logeographic clades (after } \\
\text { Brunhoff et al., 2003; Galbreath \& } \\
\text { Cook, 2004) }\end{array}$ \\
\hline \multirow{4}{*}{$\begin{array}{l}\text { M. o. } \\
\text { tschuktschorum } \\
\text { Miller, 1899, } \mathrm{n}=33\end{array}$} & 38 & Kuvet River, Chukotka & 7 & Beringian \\
\hline & 39 & Amguema River, Chukotka & 13 & Beringian \\
\hline & 40 & Anadyr' & 10 & Beringian \\
\hline & 41 & Koryakskaya Zemlya & 3 & No data \\
\hline \multirow{3}{*}{$\begin{array}{l}\text { M. o. } \\
\text { kamtschaticus } \\
\text { Pallas, } 1779, \mathrm{n}=26\end{array}$} & 42 & Karaginskii Island & 3 & No data \\
\hline & 43 & Kamchatka River, Kamchatka & 20 & Beringian \\
\hline & 44 & Cape Lopatka, Kamchatka & 3 & No data \\
\hline \multirow{2}{*}{$\begin{array}{l}\text { M. o. subsp. indet., } \\
\mathrm{n}=11\end{array}$} & 45 & Svyatogo Lavrentiya Island & 4 & Beringian \\
\hline & 46 & Alaska & 7 & Beringian \\
\hline
\end{tabular}

Sheremet'eva, 2005). Therewith, comparative craniometric analysis has been carried out only for 16 populations in the north-eastern part of the Palaearctic range (Kostenko \& Allenova, 1986). No comprehensive examination of craniometric variation and evaluation of morphological differentiation of recent population over the whole range has been attempted yet. At the same time an extensive phylogeographic species-wide studies with the use of molecular marker-mitochondrial cytochrome $b$ gene has recently been accomplished (Brunhoff et al., 2003; Galbreath \& Cook, 2004). Despite the obvious significance of these studies in elucidation of recent genetic differentiation and distributional history, the common drawback of most phylogeographic works thus performed is inadequate sample size. The obvious reason for that the variation is largely ignored is, namely, constraints on funding and effort that restricted the number of individuals that could practically be studied and unsuitability of museum specimens for wide scale molecular studies. Inadequate sample representation in the majority of phylogeographic studies performed on wide-ranged species often results in false controversy of molecular and morphological data. Our purpose is to review variation in cranial characters in $M$. oeconomus based on statistically defined differences among populations, to check whether currently recognized subspecies morphometrically recognizable with a sufficient confidence, to compare the levels of morphological and molecular divergence, to test the probable scenarios of evolutionary histories and finally to discuss the taxonomic implications of our results.

\section{Material and methods}

A total of 353 skull samples from 46 localities across the species range in Eastern Europe, most of Asia and partly of North America from the collections of the Zoological Institute of the Russian Academy of Sciences in St. Petersburg were measured. The data on the geographic localities and the size of the samples studied are given in Tab.1 and Fig.1.

For each adult specimen 27 cranial measurements (Fig. 2) were taking to the nearest $0.1 \mathrm{~mm}$ using dial calipers.

Sexual dimorphism was assessed with ANOVA, using one-way design of males against females, where samples were sufficiently large $(n>15)$. The results have shown that there are no statistically significant differences between sexes, so subsequent analyses used the samples with sexes combined.

Specimens of $M$. oeconomus were grouped according to currently recognized subspecies (Gromov \& Erbaeva, 1995) and compared using forward stepwise discriminant function analysis. Squared Mahalonobis distances $\left(D^{2}\right)$ were used to assess how different or similar groups were to each other. Canonical variate analysis (CVA) was performed to discover those cranial variables that best discriminate between samples and to reveal groups most similar to each other. The relative contribution of each variable to each canonical variate was investigated, with those variables with large values for a given $\mathrm{CV}$ interpreted as the best discriminators between groups. The contribution of individual charac-

Figure 2. Cranial measurements for Microtus oeconomus.

1 - KBD (condylobasal length); 2 - LBC (length of the braincase); 3 - LNasal (length of the nasal bones); 4 - Lmassalv (distance from the alveolus of M1 to the edge of $\mathrm{m}$. masseter superfacialis); 5 - Ldiastup (length of the skull diastema); 6 - Lthr (length of the maxillary toothrow); 7 - Lincfor (length of the incisor foramina); 8 - Lpalate (length of the palate); 9 - Hskull (height of the skull); 10 - Hbull (height of the skull at the bullae); 11 - Lbullae (length of the bullae); 12 - Wbullae (width of the bullae); 13 - W1 (width of the skull posterior to the zygomatic arches); $14-\mathbf{W} 2$ (width of the skull at the level of bullae); $15-\mathbf{Z W}$ (zygomatic width); $16-$ Intorb (interorbital width); 17 - Wrostr (width of the rostrum); 18 - Hrostr (height of the rostrum); 19 - Lmand-1 (length of the mandible without incisor); 20 - Lmand-2 (length of the mandible with incisor); 21 - Lconalv (distance from the condylar process to the edge of the incisor alveolus); 22 - Lconins (distance from the condylar process to the edge of the incisor); 23 - Ldiast (length of the mandibular diastema); 24 - Lmandthr (length of the mandibular toothrow); 25 - Hmand (height of the mandible); 26 - HmandM1 (height of the mandible at $\mathrm{m} 1$ ); 27 - Lmassmand (distance from the edge of the alveolus of $\mathrm{m} 1$ to the edge of masseteric ridge). 


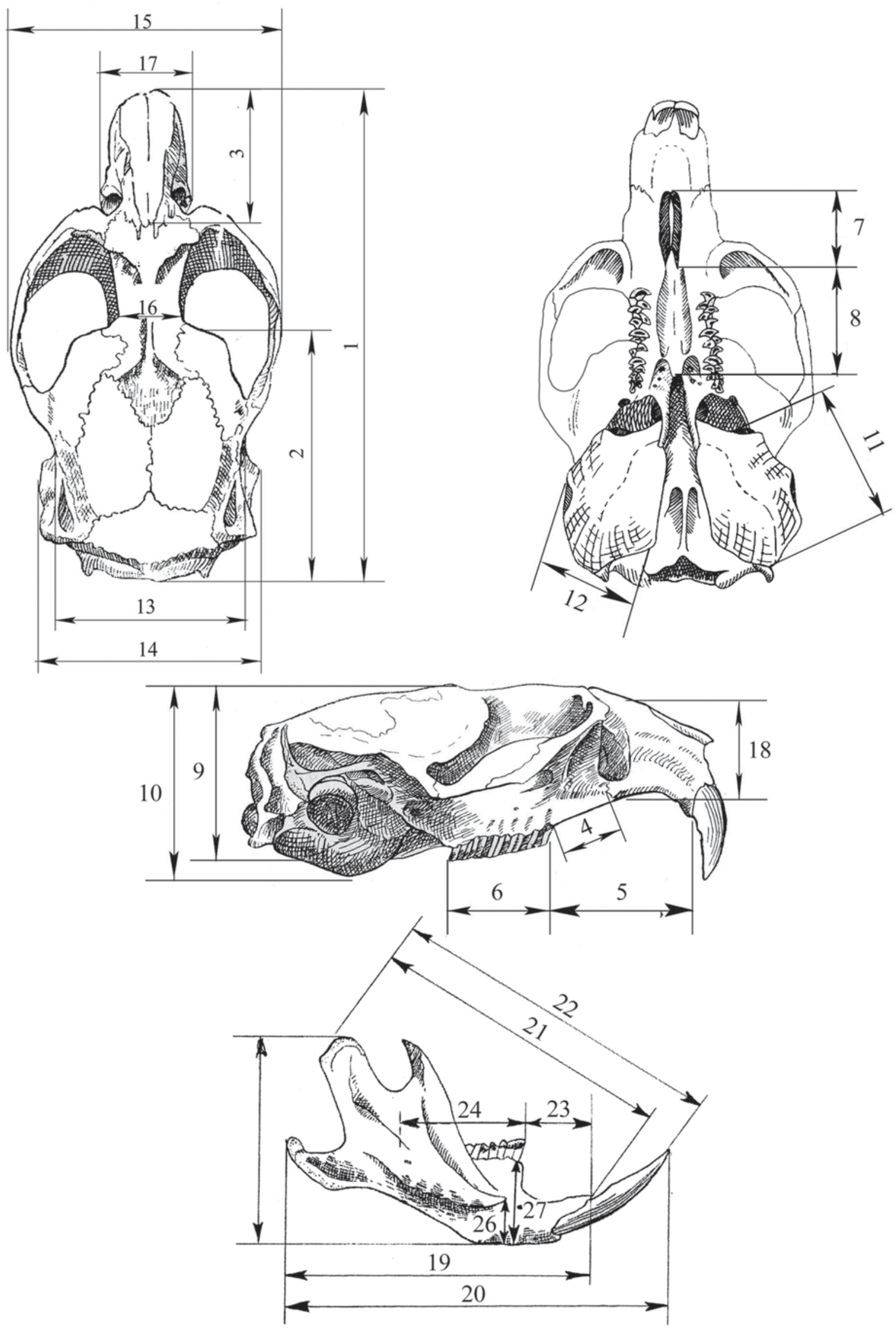




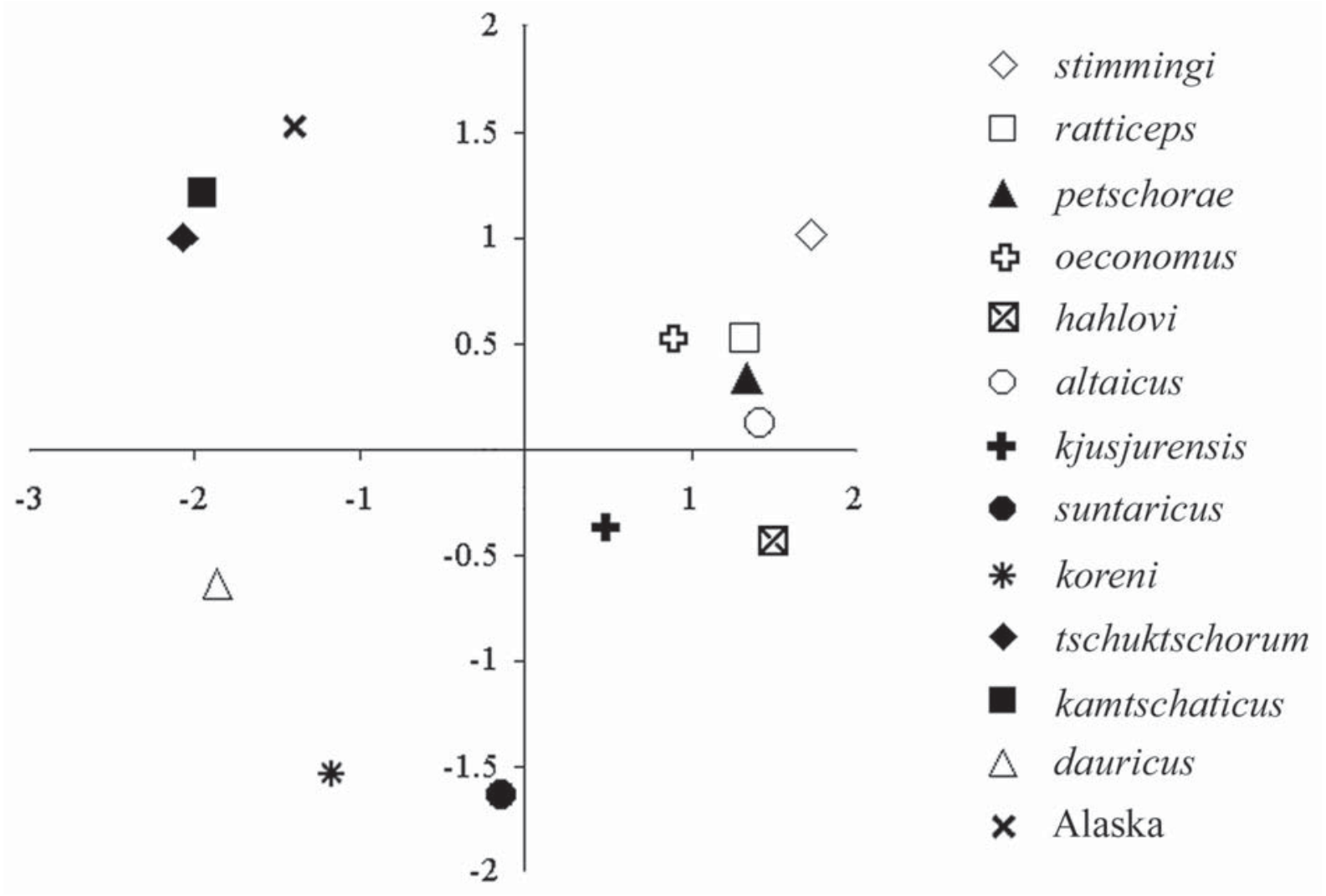

Figure 3. Projections of the centroids of the 13 subspecies samples of Microtus oeconomus onto the first two canonical variates. Symbols designating subspecies as on Fig. 1.

ters into the differences between groups was further assessed with ANOVA using one-way design.

\section{Results}

At the first step of analysis with an inclusion of all 13 subspecies two distinct subgroups of samples' centroids along the first canonical variable is clearly revealed (Fig. 3), one at the left of the graph consisting of five Palaearctic subspecies: $M$. o. dauricus, M. o. koreni, M. o. suntaricus, M. o. tschuktschorum, M. o. kamtschaticus and M. oeconomus from Alaska, and the other on the right of the graph: $M$. o. ratticeps, M. $o$. stimmingi, M. o. petschorae, M. o. altaicus, M. o. oeconomus, M. o. hahlovi, and M. o. kjusjurensis. The highest eigenvector associated with the first canonical variable is the distance from the point of attachment of $\mathrm{m}$. masseter superfacialis to the anterior edge of M1 (Lmassalv) (Fig. 2). The discriminant analysis showed no significant differentiation between $M$. o. ratticeps, $M$. o. stimmingi and $M$. o. petschorae from one hand and $M$. o. altaicus and M. o. oeconomus from another, so for further analysis we pooled specimens from these samples. The UPGMA dendrogram resulting from cluster analysis based on squared Mahalanobis distances between the new set of samples arranged in such way divided samples into two main groups (Fig. 4). The first cluster included samples of $M$. oeconomus from Kamchatka, Chukotka and Alaska. Within that cluster the sample from Chukotka appeared to be most similar to voles from Alaska. It noteworthy that the forms united in the first cluster constitute the so-called Beringian group distinguishable also by mtDNA data (Brunhoff et al., 2003; Galbreath \& Cook, 2004). The second cluster of root voles, in its turn, is divided into two distinct groups which could be conditionally designated as western and east-Siberian. The western group constitutes subspecies $M$. o. stimmingi, $M$. o. ratticeps, $M$. o. petschorae, $M$. о. altaicus, $M$. о. oеconomus, $M$. o. hahlovi and M. o. kjusjurensis. Therewith, the first five subspecies are very close to each other and hardly distinguishable, so to maximize the phenotypic dissimilarities we unite these groups on the dendrogram. The cluster which we conditionally designated as East-Siberian group constitutes subspecies $M$. o. suntaricus, M. o. koreni and M. o. dauricus. Thus, the probable border between the western and east-Siberian groups approximately goes somewhere along the Lena River at the north and Baikal region at the south (between subspecies M. o. kjusjurensis - M. o. suntaricus and M. o. kjusjurensis-M. o. dauricus. Noteworthy that the study of protein polymorphism also referred subspecies $M$. $O$. kjusjurensis and $M$. o. dauricus to different groups (Polovinkina et al., 1986). Further on, to maximize 


\author{
stimmingi \\ ratticeps \\ petschorae \\ hahlovi \\ oeconomus
}

\begin{tabular}{l|} 
altaicus \\
kjusjurensis
\end{tabular}

suntaricus

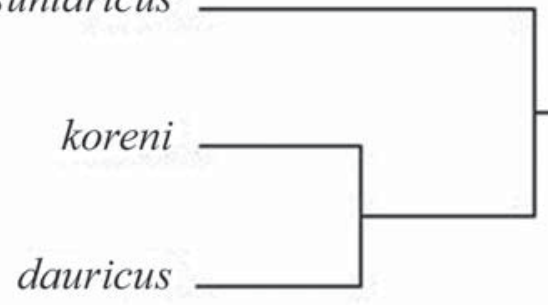

\title{
tschuktschorum
}

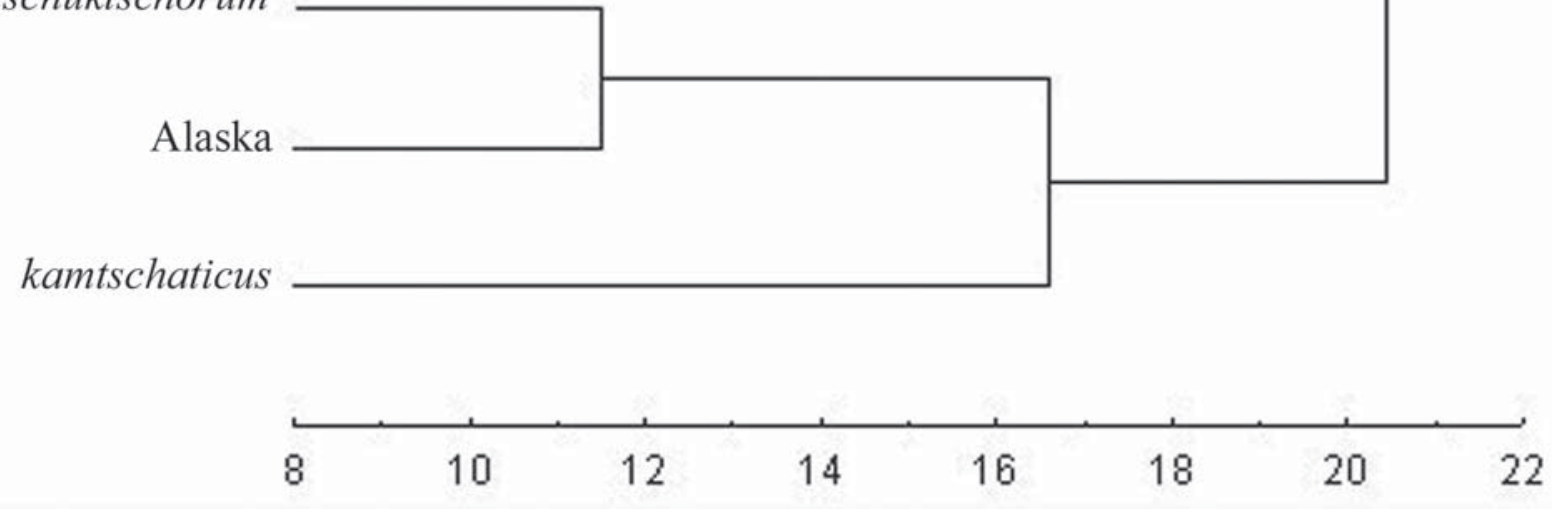

Figure 4. The UPGMA dendrogram resulting from cluster analysis of morphometric variables based on squared Mahalanobis distances between the pooled samples of Microtus oeconomus.

cranial differences between these three groups we pooled specimens in each group into one sample and performed CVA (Fig. 5A). The first canonical variate accounted for $70 \%$ of the explained variance and was weighted most heavily on variables that had the best discriminatory power: Lmassalv and Intorb. The second canonical variate accounted for $30 \%$ of the discrimination of the groups and was weighted most heavily by Lbullae, Ldiastup and W1. Beringian and EastSiberian groups tended to be separated by Lmassalv across the first canonical variate from western group and were weighted more heavily in positive direction and Beringian and East-Siberian group were well discriminated by the length of bullae, length of the upper diastema and width of the braincase (W1; Fig. 5B, C, D).
On the second step of analysis our aim was to look more thoroughly on the morphological differentiation within each of the groups and try to define more explicitly the probable border between them. The western group appeared to be rather homogeneous. The craniometric variables showed a slight tendency towards clinal variation in size from west to east. The seven taxa form a continuum on the first canonical variable with three relatively distinct subgroups, one consisting of $M$. $o$. stimmingi and $M$. o. ratticeps and the other of $M$. $o$. altaicus, M. o. oeconomus, and M. o. hahlovi from one hand and M. o. petschorae and M. o. kjusjurensis from another. Variables HmandM1, Lbullae, Wbullae had the highest eigenvectors associated with the first canonical variate and allocation of subspecies from left to 

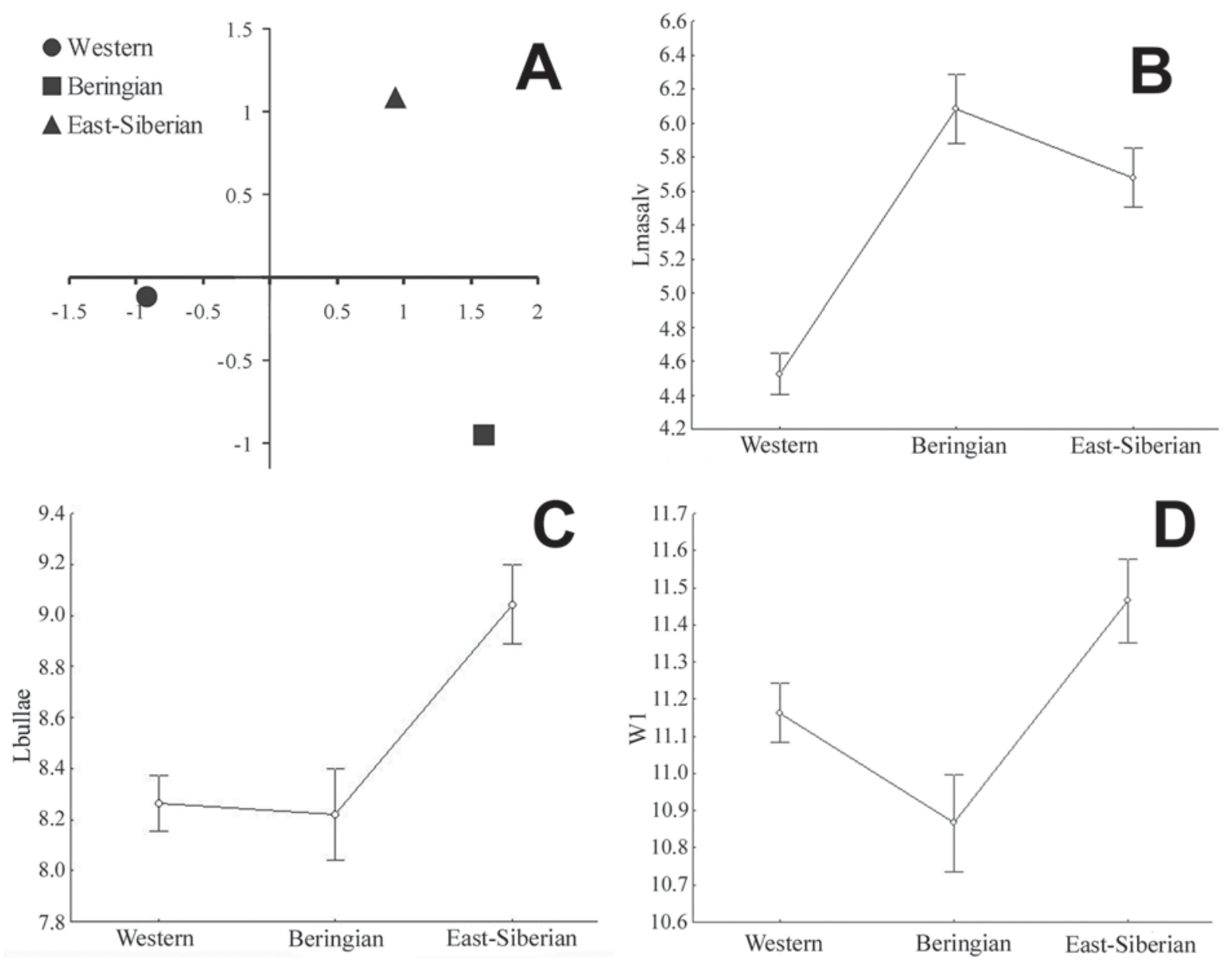

Figure 5. Comparison of the pooled samples of three main groups of Palaearctic root voles, Microtus oeconomus.

A - projections of the centroids onto the first two canonical variates; B - differences in the distance from the alveolus of M1 to the edge of $\mathrm{m}$. masseter superfacialis; $\mathrm{C}$ - differences in the length of the bullae; D - differences in the width of the skull posterior to the zygomatic arches. Vertical bars denote 0.95 confidence intervals.

right along first canonical variate characterizes eventual increase in the values of these variables.

Therewith, the summarized phenotypic similarities between these forms resulting from cluster analysis based on squared Mahalanobis distances show that the first two forms form independent cluster opposed to all other forms. M. o. altaicus and M. o. oeconomus are practically indistinguishable, $M$. o. petschorae is very close to these two, and finally, M. o. hahlovi and M. $o$. kjusjurensis are more close to one other and both to three mentioned forms. It is interesting to note that in pairwise comparison of these forms two samples of $M$. $o$. hahlovi from different banks of the Ob River significantly differed $(\mathrm{P}<0.01)$ from each other. Further on, with the purpose to define the probable border between the group of western subspecies and East-Siberian we took for special consideration the samples of subspecies M. o. altaicus, M. o. kjusjurensis and M. o. dauricus. The specimens of subspecies $M$. o. dauricus from four sites differ reliably $(\mathrm{P}<0.01)$ from all specimens of subspecies $M$. o. altaicus (four sites, $\mathrm{n}=36$; Tab. 1) and
M. o. kjusjurensis (four sites, $\mathrm{n}=41$ ) being therewith, undistinguishable within the group. Discriminant analysis classified the specimens of $M$. o. dauricus with $95 \%$ probability and $M$. o. altaicus - M. o. kjusjurensis with $69-75 \%$ probability respectively. Similar results were obtained in comparing the samples of subspecies M. o. kjusjurensis with $M$. o. suntaricus. The latter differed from all specimens of the former $(\mathrm{P}<0.01)$. This difference was most pronounced in the greatest size of the bullae and height of the skull in $M$. $o$. suntaricus. Within the East-Siberian populations $M$. $O$. dauricus formed the most distinct group clearly separated from $M$. o. suntaricus and M. o. koreni (Fig. 6A). The first form is distinguished mostly by smaller values of most variables, two latter forms are very close to one other and overlapping in many parameters, but $M$. $O$. koreni generally is larger. The group of the so-called Beringian populations most clearly differed from all East-Siberian populations by the smaller length of the bullae (Fig. 5C) and within the Beringian group root voles from Kamchatka dramatically differed from all 

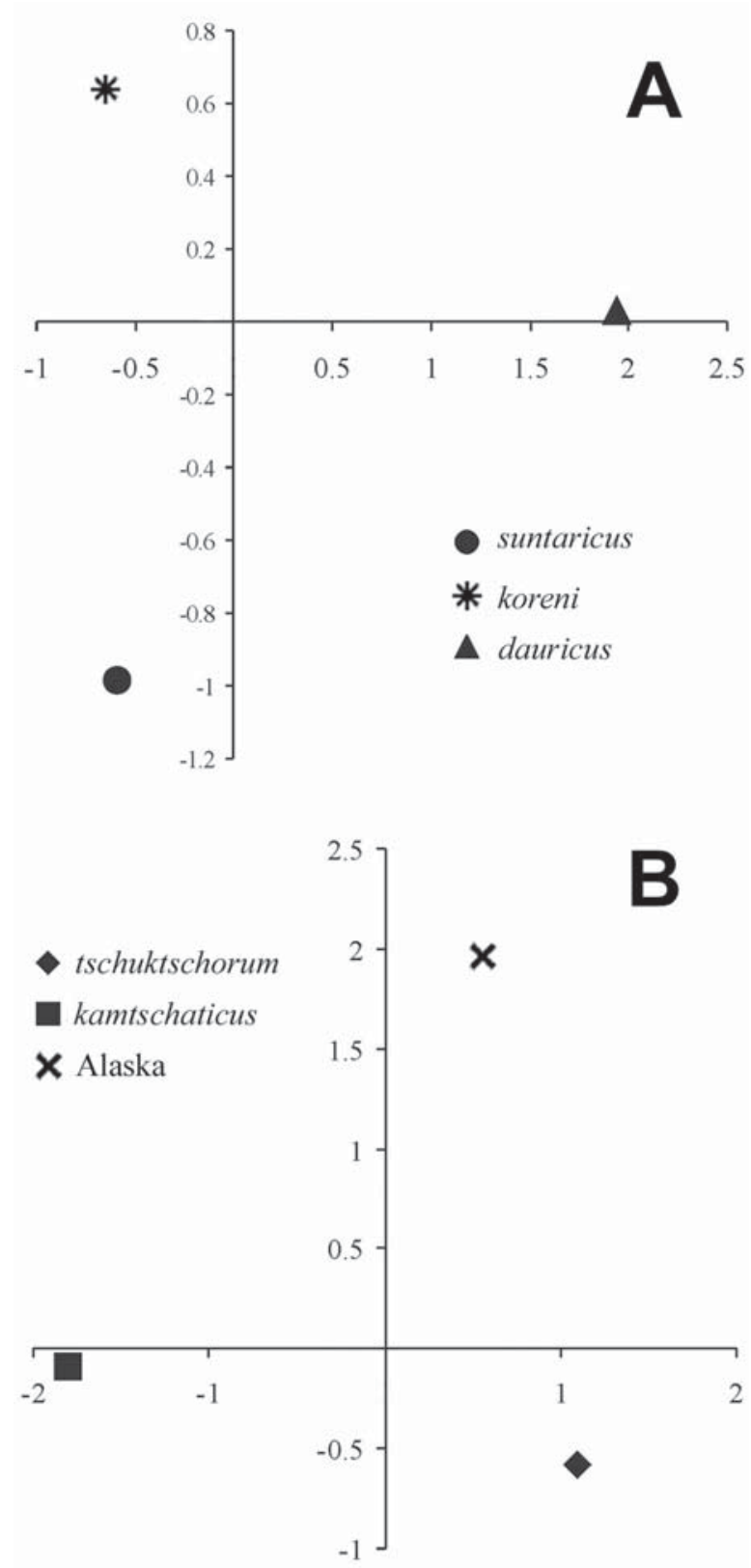

Figure 6. Projections of the centroids of the pooled samples of the subspecies of Microtus oeconomus.

A - within the East-Siberian group of root voles onto the first two canonical variates; B - within the Beringian group of root voles onto the first two canonical variates.

others by condylobasal length (greatest values; Fig. 6B) and width of zygomatic arches.

\section{Discussion}

Material examined in this work showed that only few among 13 subspecies distinguished currently in the Palaearctic could be recognized with sufficient confidence on the base of the skull variables. According to our material root voles from the northwestern part of Russia up to Taimyr and Western Siberia appeared to be less differentiated than root voles inhabiting eastern part of the range. Preliminary data do not support the independence of subspecies $M$. o. ratticeps and $M$. $o$. petschorae, $M$. o. altaicus and $M$. o. oeconomus. The range and the borders of distribution of subspecies $M$. o. stimmingi, M. o. kjusjurensis and $M$. o. altaicus should be further specified. Subspecies $M$. o. suntaricus, M. o. dauricus, M. o. koreni, M. o. tschuktschorum and M. o. kamtschaticus could be recognized with sufficient confidence on the base of craniometric differences. However, any taxonomic conclusions on the validity of subspecies and taxonomic rank of population groups could not be based exclusively on analysis of variation of morphological features or molecular data but should be also supported by reconstruction of most probable recent history of range formation and all available data set. A significant contribution to the understanding of distributional history of species has been achieved in the last decades with an application of molecular markers and wide distribution of phylogeographic studies (Hewitt, 1999, 2000; Brunhoff et al., 2003; Galbreath \& Cook, 2004 and others). Despite the evident advantages of this method it has some certain limitations, in particular, as it was already stated above, most often too small number of specimens are involved in the analysis. Below we compare results of our study of craniometric variation with phylogeographic studies based on cytochrome $b$ variation (Brunhoff et al., 2003; Galbreath \& Cook, 2004). The consistency in results of morphological and molecular analysis will no doubt make historical reconstruction more plausible, discrepancies in its turn will help to contour the points for further investigations.

Our study of craniometric variation in the samples of the root voles revealed both consistency and discrepancies in the set of morphological and molecular data. Among the largest discrepancy should be noted the strongly supported morphological differentiation within the Palaearctic on the west and east group with an approximate border near the Lena River, whereas molecular investigations (Brunhoff et al., 2003) refer all the voles from the vast territory from Urals to the Kolyma River to one, namely Central Asian, clade. However, in molecular analysis were included only six specimens from five sites that is evidently insufficient for any conclusions. It should be noted here that the geographic border of the split on the west and east groups of populations discovered here in M. oeconomus on craniometric data almost coincide with one found in Lemmus sibiricus Kerr, 1792 which in its turn is supported both by molecular and morphological data (Abramson, 1999; Fredga et al., 1999). Both species are associated with moist habitats and such coincidence in the splits of two partly sympatric and phylogenetically not closed forms united by mutual habitat requirements evidence for common biogeographical events that formed the current pattern of genetic and morphological variation. Thus, we propose that the emphasized discrepancy could be attributed only to the insufficient material studied by molecular methods and we aware 
that further molecular investigations will remove this discrepancy. Indirect evidence for this conclusion gave and results of the biochemical studies (Polovinkina et al., 1986).

The west group unites six subspecies (see above) out of which not more than three could be supported by morphological data. Therewith, morphological data coincides with molecular in regarding all voles from the European North as representing one monophyletic group. Thus, subspecies $M$. o. ratticeps and $M$. $o$. petschorae should be considered as synonyms. The forms from Urals, West Siberia and Krasnoyarsk Territory are similar with this group. The voles from the south-west regions of Russia (M. o. stimmingi) are within the range of variation with the forms named above. Molecular studies refer the two investigated specimens belonging to this form to the North-European clade, but it is likely that future sampling will discover here the representatives of the West-European clade. The Eastern group appeared to be more differentiated in relation to the morphology of the skull and all previously described subspecies (Kostenko \& Allenova, 1989; Kostenko, 2000) are supported also by our data. The Beringian group is also differentiated morphologically. The root voles from Kamchatka seriously differ from all other populations within the Beringian group. Recently the differentiation of root voles from Kamchatka has been supported and by new molecular data (Sheremet'eva, 2005), thus it beyond doubt represent at least an independent subspecies. Craniometric data show good consistency with molecular data in placing together the samples from Chukotka and Alas$\mathrm{ka}$ in one cluster and in defining the borders between the Beringian and Asiatic clades in the region of the Kolyma River. It is noteworthy that this split between the phylogeographic groups again coincides with the split found for another tundra rodent, Lemmus. The probable history of formation of species distributional range in the Eastern Palaearctic has been considered in details earlier (Kostenko \& Allenova, 1989) and generally is well supported by the new molecular data. Distribution of the fossil remains and character of current differentiation of the species advocates for its origin and formation in the Early Pleistocene in the Eastern Palaearctic (Gromov \& Polyakov, 1977; Galkina, 1980; Galkina \& Dupal, 1982) and rather fast distribution westward along the West Siberian lowland during warm and humid interglacial periods of Middle and Late Pleistocene. It is well known that radius of individual activity of root vole is very high and it may shift its distributional range in historically short time up to hundreds kilometers (Litvin, 1980; Oparin, 2005). Fast colonization of North and West European parts of the current range from limited sources with repeated bottleneck events is in a good agreement with poor molecular and morphological differentiation of the species in this part of the range relative to Eastern one.

Finally, summarizing all said above we want to highlight some taxonomic implications of the considered results and evolutionary scenarios. We regard the subspecies M. o. suntaricus, M. o. dauricus, M. o. koreni, M. o. tschuktschorum and M. o. kamtschaticus described from the Eastern Palaearctic to be well defined and valid, though the borders of distribution for M. o. suntaricus, M. o. dauricus and $M$. o. koreni should be further specified. The differentiation on subspecies in the Western Palaearctic is much less evident and the majority of the forms of this rank described earlier appear to be artificial. Further comprehensive studies with both molecular and morphological methods and inclusion of large material from unexplored parts of the range is necessary for final elucidation of the evolutionary history and taxonomic structure of this complex species, but already on this step of our knowledge we may conclude that subspecies $M$. o. ratticeps and $M$. o. petschorae should be without any doubt considered as synonymous. $M$. o. ratticeps Kayserling et Blasius, 1841 has priority over M. o. petschorae Ognev, 1944 and thus it is the valid name for this subspecies. There is also high probability of combination of subspecies $M$. o. altaicus, M. o. oeconomus, and M. o. hahlovi into one form. Thus instead of seven subspecies we suppose that only up to four subspecies designating more or less independent evolutionary lineages may remain in the western part of the species range.

ACKNOWLEDGMENTS. Authors thank V.S. Lebedev (Zoological Museum, Moscow State University) and A.Yu. Puzachenko (Institute of Geography RAS) for helpful discussion, G.I. Baranova (Zoological Institute RAS) for the assistance with work with collections. This work was supported by the Russian Foundation for the Basic Research (project 03-04-49179), Program of Presidium RAS "Scientific Fundamentals of biodiversity conservation in Russia", and Program of Presidium RAS "Dynamics of plant, animal and human gene pools".

\section{References}

Abramson N.I. 1999. Morphometric variation in true lemmings (Lemmus) from the Eurasian Arctic // Ambio. Vol.28. No.3. P.256-260.

Belyanin A.N., Belyanin V.N. \& Gavrikova V.V. 1986. [Karyotypic characteristics of root vole (Microtus oeconomus) from different parts of the range] // Vorontsov N.N. (ed.). [The Fourth Conference of the All Union Theriological Society, Moscow, January 27-31, 1986. Abstracts]. T.1. Moskva: Theriologicheskoe Obshchestvo. P.44-45 [in Russian].

Brunhoff C., Galbreath K.E., Fedorov V.B., Cook J.A. \& Jaarola M.J. 2003. Holarctic phylogeography of the root vole (Microtus oeconomus): implications for late Quaternary biogeography of high latitudes // Molecular Ecology. Vol.12. No.4. P.957-968.

Galbreath K.E. \&.Cook J.A. 2004. Genetic consequences of Pleistocene glaciations for the tundra vole (Microtus oeconomus) in Beringia // Molecular Ecology. Vol.13. No.1. P.135-148.

Galkina L.I. 1980. [The history of faunal complexes of rodents of the southern part of western Siberia] // Bely- 
shev B.F. \& Ravkin Yu.S. (eds.). [Problems of Zoogeography and History of Fauna]. Trudy Biologicheskogo Instituta Sibirskogo Otdeleniya AN SSSR. No.40. P.221245 [in Russian].

Galkina L.I. \& Dupal T.A. 1982. [Formation and development of two species of grey voles (Microtus gregalis Pall. and M. oeconomus Pall.) on the south-east of West Siberia] // Panteleev P.A. (ed.). [The Third Conference of the All Union Theriological Society, Moscow, February 1-5, 1982. Abstracts]. T.1. Moskva: Theriologicheskoe Obshchestvo. P.23-24 [in Russian].

Gromov I.M. \& Erbaeva M.A. 1995. [The Mammals of Russia and Adjacent Territories. Lagomorphs and Rodents]. Sankt Peterburg: Zoologicheskii Institut RAN. 522 p. [in Russian].

Gromov I.M. \& Polyakov I.Ya. 1977. [Fauna of the USSR. Mammals. Tome III. Vyp.8. Voles (Microtinae)]. Leningrad: Nauka. 504 p. [in Russian].

Fredga K., Fedorov V.B., Jarrell G.H. \& Jonsson L. 1999. Genetic Diversity in Arctic Lemmings // Ambio. Vol.28. No.3. P.261-269.

Frisman L.V., Kartavtseva I.V., Kostenko V.A., Sheremet'eva I.N. \& Chernyavskii F.B. 2003. [Genogeographic variation and genetic differentiation of root vole (Microtus oeconomus Pallas, 1776, Cricetidae, Rodentia) from Kuril Islands] // Genetica. Vol.39. No.10. P.1363-1372 [in Russian, with English summary].

Hewitt G.M. 1999. Post-glacial recolonisation of European biota // Biological Journal of the Linnean Society. Vol.68. No.1-2. P.87-112.

Hewitt G.M. 2000.The genetic legacy of the Quaternary ice ages // Nature. Vol.405. No.6789. P.907-913.

Kostenko V.A. \& Allenova T.V. 1986. [Intraspecies taxonomy of the root vole (Microtus oeconomus Pallas, 1778) in the North-Eastern Palaearctic // Vorontsov N.N. (ed.). [The Fourth Conference of the All Union Theriological Society, Moscow, January 27-31, 1986. Abstracts]. T.1. Moskva: Theriologicheskoe Obshchestvo. P.68-69 [in Russian].

Kostenko V.A. \& Allenova T.V. 1989. [Intraspecies differentiation of the root vole in the Far East and the distributional history of its subspecific form] // Kostenko V.A. (ed.). [Teriological Studies of the Southern Far East]. Vladivostok: Dal'nevostochnoe Otdelenie AN SSSR. P.425 [in Russian].

Kostenko V.A. 2000. [Rodents (Rodentia) of the Far East of Russia]. Vladivostok: Dal'nauka. 208 p. [in Russian, with English summary].

Kozlovskii A.I. \& Khvorostyanskaya L.P. 1978. [Stability of chromosome numbers in some species of rodents of the North-Eastern Siberia] // Kontrimavichus V.L. (ed.). [Fauna and Zoogeography of Mammals of the North-Eastern Siberia]. Vladivostok: Dal'nevostochnyi Nauchnyi Tsentr AN SSSR. P.106-119 [in Russian].

Král B. 1972. Chromosome characteristics of Muridae and Microtinae from Czechoslovakia // Přirodovedné. Práce ústavů Československé, Brne. Vol.6. No.12. P.35-43.

Lance E.W. \& Cook J.A. 1998. Biogeogragraphy of tundra voles (Microtus oeconomus) of Beringia and the southern coast of Alaska // Journal of Mammalogy. Vol.79. No.1. P.53-65.

Litvin V.Yu. 1980. [Common voles and mountain voles] // Kucheruk V.V. (ed.). [Questions of Theriology. Results of Marking of Mammals]. Moskva: Nauka. P.220-247 [in Russian].

Makino S. 1950. Studies on murine chromosomes. VI. Morphology of the sex chromosomes in two species of $M i$ crotus // Annotationes zoologicae Japonensis. Vol.23. No.2. P.63-68.

Matthey R. 1954. Nouvelles recherches sur les chromosomes des Muridae // Caryologia. Vol.6. No.1. P.1-44.

Nadler C.F., Rausch V.R., Lyapunova E.A., Hoffmann R.S. \& Vorontsov N.N. 1976. Chromosomal banding patterns of the Holarctic rodents Cletrionomys rutilus and Microtus oeconomus // Zeitschrift für Säugetierkunde. Bd. 41. Hf.3. P.137-147.

Oparin M.L. 2005. [Changes in rodent population of typical and dry steppe of Volga Region in XX century] // Abramson N.I. \& Averianov A.O. (eds.). [Systematics, Paleontology, and Phylogeny of Rodents]. Trudy Zoologicheskogo Instituta RAN. T.306. P.82-101 [in Russian, with English summary].

Polovinkina R.A., Litvinov Yu.N., Yudina S.A. \& Glazko V.I. 1986. [Analysis of intraspecies variation of the root-vole based on complex of characters] // Izvestiya Sibirskogo Otdeleniya AN SSSR, Seriya Biologicheskie Nauki. No.13(424). Vyp. 2. P.110-115 [in Russian, with English summary].

Sheremet'eva I.N. 2005. [Morphological and genetic variation of Microtus fortis Büchner, 1889 and root-vole Microtus oeconomus Pallas, 1776 (Microtinae, Rodentia) in the Far East of Russia]. Avtoreferat dissertatsii. Vladivostok. 22 p. [in Russian].

Vorontsov N.N., Lyapunova E.A., Boeskorov G.G. \& Revin Yu.V. 1986. [The stability of root vole (Microtus oeconomus) karyotype in the central part of the range and the history of formation of recent range of the species] // Zoologicheskii Zhurnal. T.65. No.11. P.1705-1715 [in Russian, with English summary]. 